\title{
Proterozoic Crustal Evolution in Southwestern Africa
}

\author{
by Chris Hartnady, Pieter Joubert and Clive Stowe
}

This article reviews recent work on the precambrian shield of Southern Africa between the northeastern, $3.5 \mathrm{Ga}-0 \mathrm{Id}$, Kaapvaal and Zimbabwean Archaean nucleii and the south-western Late Proterozoic-Early Palaeozoic belts. In the latter part of the subcontinent, no confirmed trace of Archaean crust has yet been found, the oldest fragment being the 2.0 Ga-old, volcanoplutonic Richtersveld Subprovince. Paleomagnetic reconstructions suggest the existence in the late Precambrian of the Adamastor Ocean, separating cratonic blocks in southern Africa and extending into South America and Antarctica.

\section{Proterozoic Tectonic Divisions}

Southern African Proterozoic provinces are generally considered to have originated during three main chelogenic cycles, known elsewhere in Africa as the Eburnean, Kibaran and Pan-African episodes. A clearer pattern (Fig. 1 and Table 1) of tectonic subprovinces and terranes is now emerg- ing (Stowe, Hartnady and Joubert, 1984), complicating the earlier view of extended Precambrian crust-forming cycles and showing that individual parts of the major provinces evolved separately over time-scales much briefer than 500 to $1,000 \mathrm{Ma}$. For the present, however, a three-fold division into Early, Middle and Late Proterozoic crustal provinces is retained.

In the Early Proterozoic Kgalagadi (Kalahari) Province, the Kheis and Magondi subprovinces evolved between 2.0 and 1.7 $\mathrm{Gr}$ in equivalent positions along the western flanks of the Kaapvaal and Zimbabwe (Rhodesian) Archaean provinces. Largely concealed by an extensive Phanerozoic sedimentary veneer, their internal subdivision is inferred from geophysical surveys, isolated exposures and borehole data. The Middle Proterozoic Namaqua Province is a broad high grade region extending for $2,000 \mathrm{~km}$ across the southern flank of the Kaapvaal Province.

The Natal, Gordonia and Bushmanland subprovinces consist of supracrustal paragneisses, orthogneisses, charnockites, granitic plutons and pegmatite belts, with a 1.2-0.9 Ga metamorphic-plutonic history. The Richtersveld Subprovince, a low-grade Early Proterozoic (2.0-1.8 Ga) volcanoplutonic complex, is widely separated from the Kgalagadi Province by younger highgrade terranes. The enigmatic Rehoboth Subprovince is hidden beneath relatively undeformed Late-Precambrian, Nama and Permian to Jurassic, Karoo cover sequences above an unknown basement.

The Late Proterozoic to Early Palaeozoic Damara Province includes the Khomas and Swakop belts of Namibia (the Damara Orogen sensu stricto), the Saldania Belt (SW Cape Province) and the Gariep Belt (Atlantic coastal region). Recent tectonic and geochronological studies in these subprovinces suggest that "Pan-African" orogeny occurred during at least two distinct phases, the most recent culminating at about $530 \mathrm{Ma}$ ago (Miller, 1983a).

Regional gravity and aeromagnetic surveys in the central, sand-covered Kalahari region define crustal tectonic units. For example, continuity between the Damara Province and the Lufilian Arc and Zambezi Belt of central Africa is indicated by prominent linear magnetic anomalies

Figure 1: Major tectonic provinces and subprovinces of Southern Africa. $K=$ Kalahari Line; $P=$ Pofadder Shear Zone; S.C.C.B. = Southern Cape Conductive Belt; $T=T$ shane and $X=$ Xade Mafic Complexes. 
TABLE 1 .

SUMMARY OF TECTONIC PROVINCES IN SOUTHWESTERN AFRICA

\begin{tabular}{|c|c|c|c|c|}
\hline $\begin{array}{l}\text { PROVINCE and } \\
\text { Subprovince }\end{array}$ & Terrane & Regional Geological Features & $\begin{array}{l}\text { Regional } \\
\text { Trend }\end{array}$ & $\begin{array}{l}\text { Deformation } \\
\text { Ages (Ma) }\end{array}$ \\
\hline DAMARA & & & & \\
\hline$\overline{\text { Kaoko Belt }}$ & .... -... & Northern "arm" of the Damara Orogen. & North & ...- \\
\hline Swakop Belt & ---- & Low $P$, high $T$ belt with main igneous and plutonic activity. & ENE & $675-530$ \\
\hline Khomas Belt & $\begin{array}{l}\text { Kuiseb } \\
\text { Hakos-Auas }\end{array}$ & $\begin{array}{l}\text { High P, low T belt. Intense asymmetric thrust and shear belt. } \\
\text { Naukluft nappe complex, SSE-vergent. }\end{array}$ & $\begin{array}{l}\text { ENE } \\
\text { ENE }\end{array}$ & $\begin{array}{l}675-530 \\
675-530\end{array}$ \\
\hline Zambezi Belt & ---- ---- & Medium-high grade paragneiss and granite plutons. & ENE & $1200-530$ \\
\hline Gariep Belt & $\begin{array}{l}\text { Marmora } \\
\text { Port Nolloth }\end{array}$ & $\begin{array}{l}\text { W-vergent allochthonous thrust complex with "ophiolitic" } \\
\text { Grootderm sheet. } \\
\text { Thrust complex. }\end{array}$ & $\begin{array}{l}N-S \\
N N W\end{array}$ & $\begin{array}{l}700-530 \\
686-525\end{array}$ \\
\hline Saldania & $\begin{array}{l}\text { Boland } \\
\text { Swartland } \\
\text { Tygerberg }\end{array}$ & $\begin{array}{l}\text { Clastic and carbonate sequence with thrusts. } \\
\text { Phyllitic terrane, polyphase deformation and NNW sinistral shears. } \\
\text { Greywacke/phyllitic turbidites, sub-vertical folds and NNW shears. }\end{array}$ & NW & 520 \\
\hline NAMAQUA & & & & \\
\hline Natal & $\begin{array}{l}\text { northern } \\
\text { southern }\end{array}$ & $\begin{array}{l}\text { Tugela gneissic complex thrust over low-grade "ophiolite" sequence. } \\
\text { Granulitic gneiss, charnockite and granite. Polyphase deformation. }\end{array}$ & $E-W$ & $1200-900$ \\
\hline Bushmanland & various & $\begin{array}{l}\text { Para and orthogneiss; charnockite and granite. Several phases of } \\
\text { deformation including early S-vergent recumbent folds and thrusts } \\
\text { and late NW, dextral shear zones. }\end{array}$ & var. & $1700-1000$ \\
\hline Gordonia & $\begin{array}{l}\text { Kakamas } \\
\text { Upington }\end{array}$ & $\begin{array}{l}\text { High-grade supracrustals, granulite, orthogneiss, charnockite, } \\
\text { late granites. Polyphase folding including early } 5 W \text {-vergent thrusts } \\
\text { and late NW, dextral shears. } \\
\text { Transitional terrane of Kheis Province rocks, re-folded and } \\
\text { metamorphosed by Namaqua orogeny. Includes also Namaqua-age } \\
\text { volcanics (Jannelsepan and Wilgenhoutsdrif). NE-vergent isoclines } \\
\text { and thrusts. Late dextral faults. }\end{array}$ & NW & $1300-950$ \\
\hline Rehoboth & $\cdots+--$ & $\begin{array}{l}\text { Late-Proterozoic to Mesozoic platform cover above unknown } \\
\text { basement. }\end{array}$ & $-\cdots$ & $?$ \\
\hline Richtersveld & 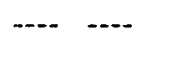 & $\begin{array}{l}\text { Calc-alkaline basalt, andesite, acid lavas and volcaniclastics } \\
\text { deformed by "Orange River" orogeny, intruded by Vioolsdrif Suite. }\end{array}$ & $E-W$ & $2000-1730$ \\
\hline$\frac{\text { KGALAGADI }}{\text { Kheis }}$ & & & & \\
\hline $\begin{array}{l}\text { Kheis } \\
\text { Magondi }\end{array}$ & $\begin{array}{l}\text { various } \\
\text { various }\end{array}$ & $\begin{array}{l}\text { Thin-skinnned fold and thrust belt, E-vergent. Quartzite, phyllite } \\
\text { metabasite sequence. } \\
\text { Fold and thrust belt, SE-vergent, orthoquartzite-carbonate sequence. }\end{array}$ & $\begin{array}{l}\text { N-S } \\
\text { NNE }\end{array}$ & $\begin{array}{l}2100-1760 \\
2000\end{array}$ \\
\hline KAAPVAAL & ---- & Archaean craton, greenstone belts, tonalitic gneiss, granite. & ENE & $3600-2600$ \\
\hline ZIMBABWE & ---- -..- & Archaean craton, greenstone belts, tonalitic gneiss, granite. & var. & $3600-2600$ \\
\hline
\end{tabular}

across northwestern Botswana. An interpreted contour map of depth to magnetic basement shows the southern Damara-Zambezi belt margin as a thrust front, flanked along its southeastern side by deep marginal basins (Pretorius, 1984).

Continuity between the Natal and Bushmanland belts of the Namaqua Province, and the position of the Archaean craton-Namaqua Province boundary beneath the Mesozoic cover and Cape Fold Belt, is indicated by a characteristic gravity profile signature (De Beer and Meyer, 1983). The "Kalahari Line" along the $22^{\circ} \mathrm{E}$ meridian, separating deep (> $15 \mathrm{~km}$ ) magnetic basement in the west from the Kheis Belt and shallow cratonic basement to the east (Hutchins and Reeves, 1980), is a distinct positive gravity and magnetic anomaly marked also by the Tshane and Xade mafic-ultramafic complexes. It might be a pre-Namaqua rifted continental margin.
The buried southern boundary of the Namaque Province has been located by geomagnetic induction surveys in a 1,200 $\mathrm{km}$-long feature now called the Southern Cape Conductive Belt, coincident with the major Beattie static magnetic anomaly (De Beer et al., 1982). Combined geophysical data indicate the presence of a highly conductive, magnetic and dense rock mass at relatively shallow crustal depth, possibly partially serpentinized basic rocks marking oceanic crust subducted from the south. This suggests that the Namaqua Province did not form intracratonically but rather along a continental margin as a Cordilleran or Andean-type mountain belt (De Beer and Meyer, 1983).

\section{The Early Proterozoic Kheis Belt}

The Kheis Belt, extending north along the western margin of the Kaapvaal Province for some $400 \mathrm{~km}$ into southern Botswana, is structurally quite distinct from and older than the Namaqua Province. Recent field mapping has shown that 

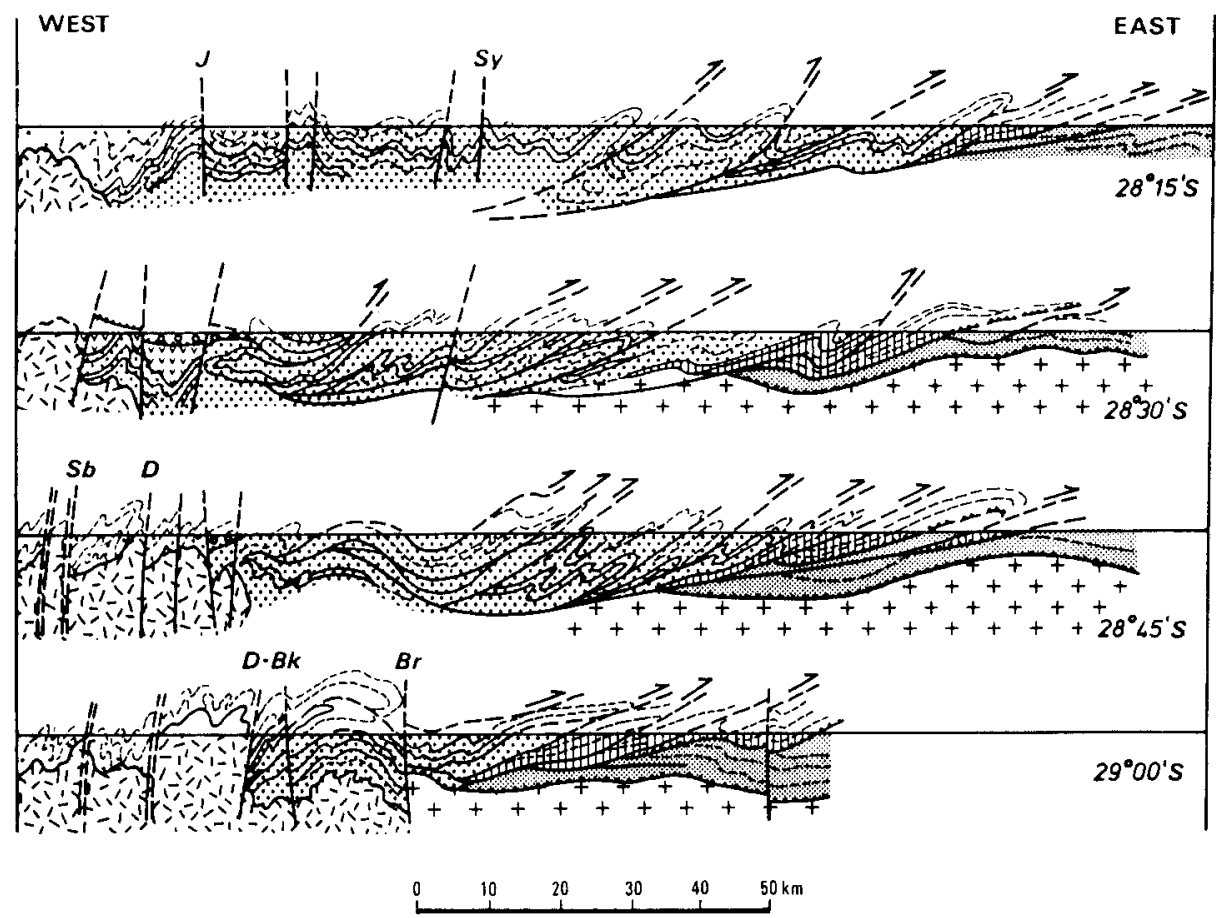

EXPLANATION

\begin{tabular}{|c|c|}
\hline 00 & Koras Group \\
\hline X:7 & Namaqua Granitoids \\
\hline 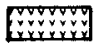 & Wilgenhoutsdrif \\
\hline & $\begin{array}{l}\text { Namaqua Metamorphic } \\
\text { Complex }\end{array}$ \\
\hline & $\begin{array}{l}\text { Shear zone } \\
\text { Fault }\end{array}$ \\
\hline
\end{tabular}

\begin{tabular}{|c|c|}
\hline \% & Kaaien/Groblershoop \\
\hline & Matsap Quartzites \\
\hline & Vaalian Sequences \\
\hline & Archaean basen \\
\hline
\end{tabular}

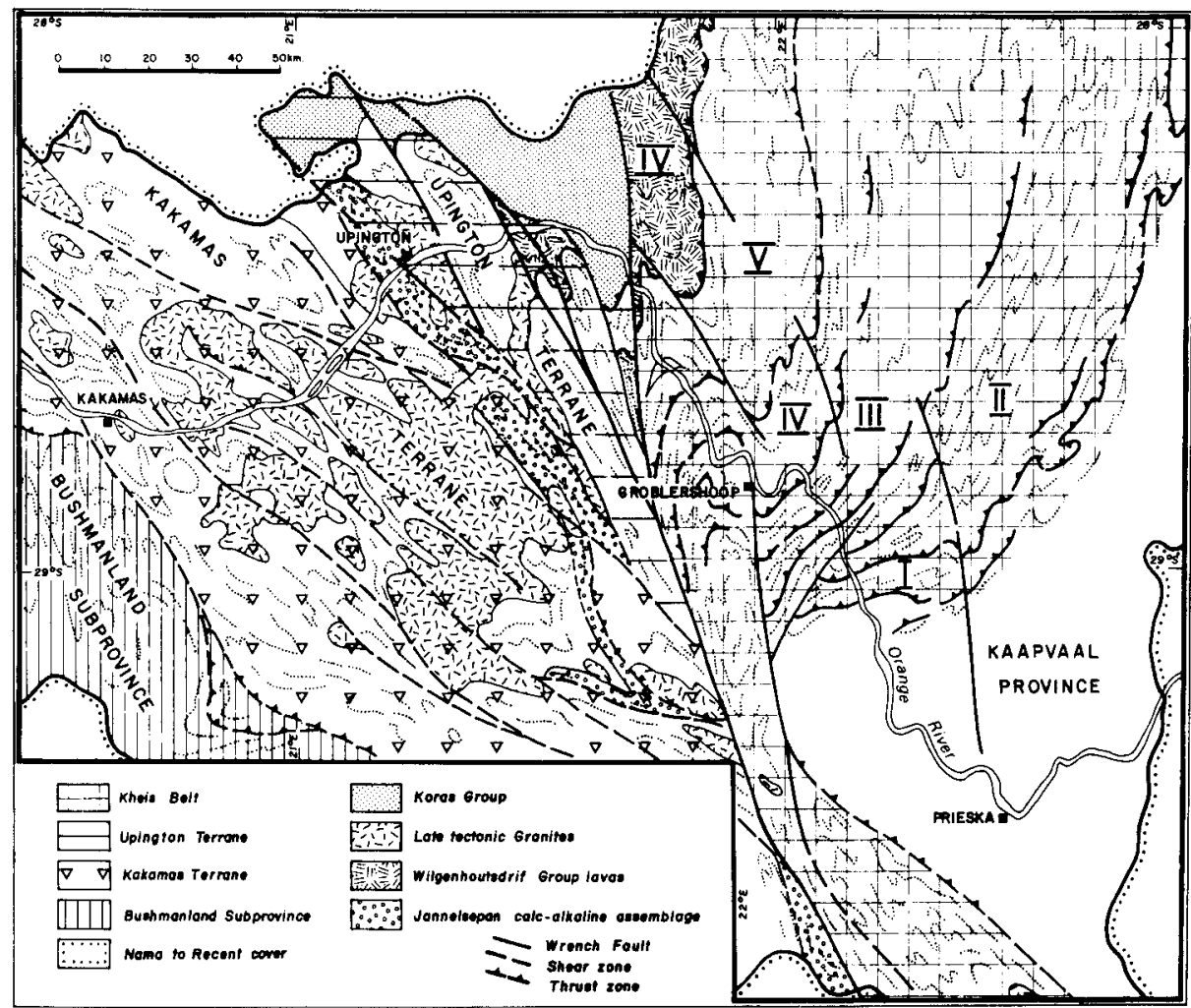

Figure 2: Profiles of thinskinned thrusting across the Kheis Belt. Faults: Bk - Brakbos; $B r$ - Brulpan; D - Doornberg; J Jebeko; $S b$ - Straussburg; $S y$ Strydenberg.

it is a thin-skinned fold-and-thrust belt (Fig. 2) developed in a 2.0 Ga-old quartzite-phyllite and amphibolite sequence (Stowe, in press). A transition from the epeiric carbonate and iron-formation shelf deposits of the Transvaal basin (2.5-2.3 Ga) to the Kheis Belt is marked by unconformable fluvial red-bed type quartzites deposited as a series of prograding clastic wedges from the cratonic source terrane. The basal Hartley Formation basalts provide an older age limit of $2068 \pm 70 \mathrm{Ma}$ (Rb-Sr) for this sequence (Barton and Burger, 1983).

Extensive thrusting both within and beneath the succeeding quartzite and phyllite sequence has produced a tectono-stratigraphic succession consisting of at least five major thrust sheets (shown by Roman numerals in Fig. 3) separated by mylonites. Mafic schist and amphibolite are particularly abundant along the western margin of the Kheis Belt, suggesting a volcanic fringe. Thrusting was directed eastwards and large-scale recumbent folds (Fig. 4) display eastwards tectonic vergence, towards the craton. Metamorphic grades are low, but rare kyanite that has escaped widespread retrograde sericitization suggests earlier high pressures.

Lenses of gneissic granite incorporated in some of the thrust slices are not interpreted as basement wedges because in detail they display intrusive contact relationships. Minimum $\mathrm{U}-\mathrm{Pb}$ model ages range from 1485-1268 Ma (Barton and Burger, 1983) near the Namaqua boundary in the south to about $1800 \mathrm{Ma}$ in the north.

\section{The Middle Proterozoic Namaqua} Province

The Namaqua Province was recently the focus of a National Geodynamies Program involving five South African universities and research institutes and summarized in Blignault et al. (1983), Joubert (1981) and Stowe $(1983,1984)$. It is a regional gravity high, suggesting high-density lower crust different from that of the Archaean crustal provinces. Deep seismic refraction profiles across Namaqualand indicate a relatively high velocity crustal layer $(\sim 6.6$

Figure 3: Regional pattern of tectonic terranes in the Gordonia and Kheis Belts. Roman numerals indicate thrust sheets. 


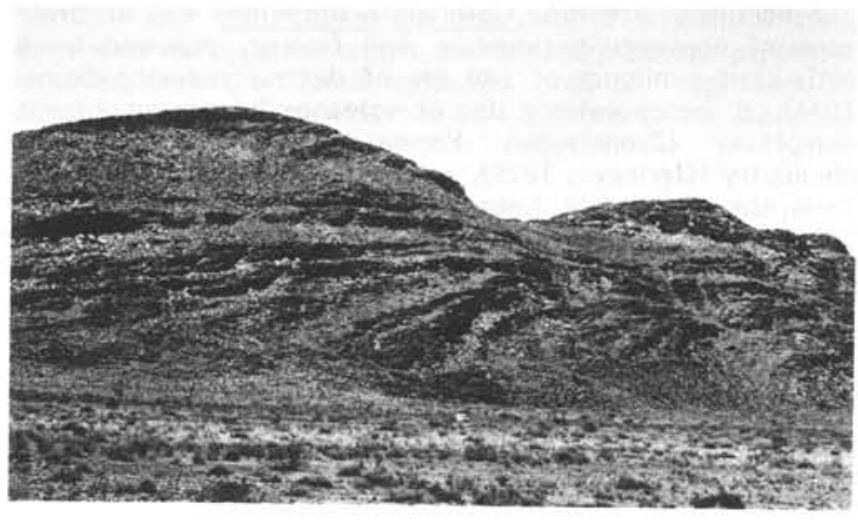

Figure 4: A large-scale recumbent fold and thrust in the Skeurberg, Kheis Belt. Landrover for scale.

$\mathrm{km} / \mathrm{s}$ ), perhaps approaching dioritic-gabbroic composition, at 15-40 km depths beneath the granulite terranes (R.W. Green, personal communication, 1985).

Recent Nd isotope studies of lower crustal xenoliths from Mesozoic kimberlites cutting the Namaqua Province suggest that, in contrast to the Archaean craton sub-crustal lithosphere, a major part of the lithosphere beneath the Proterozoic belts stabilized around 1.4-1.0 Ga (Hawkesworth, personal communication, 1984). New $\mathrm{Rb}-\mathrm{Sr}, \mathrm{Pb}-\mathrm{Pb}, \mathrm{Th}-\mathrm{Pb}$ and $\mathrm{Sm}-\mathrm{Nd}$ isotopic data (Barton and Burger, 1983) allow the recognition of at least two significant crust-forming events in Namaqualand. An older "Orange River" orogeny is indicated by 2.0-1.7 Ga ages in the Richtersveld and adjacent sectors of the Bushmanland Subprovince, and a younger "Namaqua Event" is dated at about 1.3-1.0 Ga.

In the Richtersveld Subprovince (Fig. 5) mafic and felsic lavas, ignimbrites and volcanic rocks are interbedded with minor sediments (Blignault et al., 1983), including distinctive quartzites, pelitic schists and banded iron formations. In high-grade metamorphic areas, the supracrustals are transformed to amphibolitic and quartzo-feldspathic gneisses containing some calc-silicate rocks, aluminous metapelites with sillimanite nodules, and also cordierite-anthophyllite rocks.

The Vioolsdrif Suite penecontemporaneously intruded this calc-alkaline volcanogenic pile and covers some $30,000 \mathrm{~km}^{2}$. Petrographically and geochemically, it consists almost entirely of I-type granitoids and com-

Figure 5: The pattern of tectonic terranes in the Richtersveld and Bushmanland Subprovinces.

$A T$ - Auas Terrane;

GT - Garies Terrane;

JPB - Jannelsepan Belt;

KT - Kakamas Terrane;

OT - Okiep Terrane;

$P T$ - Pela Terrane;

TVB - Tantalite Valley Belt;

$U T$ - Upington Terrane;

VT - Vioolsdrif Terrane;

WB - Wortel Belt;

GD - Groothoek Thrust;

WD - Wilgenhoutsdrif Formation. pares with similar igneous rocks of Cenozoic age found along island-ares and active continental margins (Reid and Barton, 1983). An early phase of basic to intermediate magmatism at about $1.9 \mathrm{Ga}$ was followed by felsic plutonism at $1730 \pm 20$ Ma (Reid, 1982). The currently preferred model involves the 2.0-1.9 Ga formation of an island-are complex and its later remobilization at depth along an active continental margin (D.L. Reid, personal communication, 1984).

Near the southern boundary of the Richtersveld, irregularly shaped amphibolite-serpentinite bodies of gabbro through olivine norite to peridotite are dated at $1971 \pm 96 \mathrm{Ma}$ (Reid, 1982). Farther south a relatively narrow zone of grey biotite gneiss with mafic intrusives separates the Richtersveld and Bushmanland Subprovinces. Mafic rocks on this sinuously folded, $350 \mathrm{~km}$-long "Wortel Belt" (Fig. 5) may also have a $2.0 \mathrm{Ga}$ age (H.S. Welke and C.B. Smith, personal communication, 1984). It extends westward into the Groothoek Thrust (Blignault et al., 1983), a major north-dipping mylonitic ductile shear zone. Along this southwestern boundary, the low grade Richtersveld Subprovince was thrust southwards over the higher-grade northern terrane of the Bushmanland Subprovince.

The Bushmanland Subprovince (Fig. 5) consists of intensely deformed, high grade gneisses, granulites and granitoids. A distinction between pre-Namaquan "basement" rocks and Namaquan supracrustal cover rocks is difficult and controversial. Opinions divide over the classification of certain paragneisses, whether they are of sedimentary or voleanic origin, and how they might be distinguished from syntectonic orthogneisses. Added to this is the question of whether much of the Bushmanland Subprovince is tectonically and anatectically "reworked" Archaean crust, as Kröner (1977) argued, or reworked Early Proterozoic crust of mixed volcanoplutonic character, similar to that exposed in the Richtersveld Subprovince. Certain heterogeneous banded and "grey" gneiss assemblages might be vestigial basement in which a deformation phase predating the surrounding aluminous schistose gneisses and quartzites can be recognized.

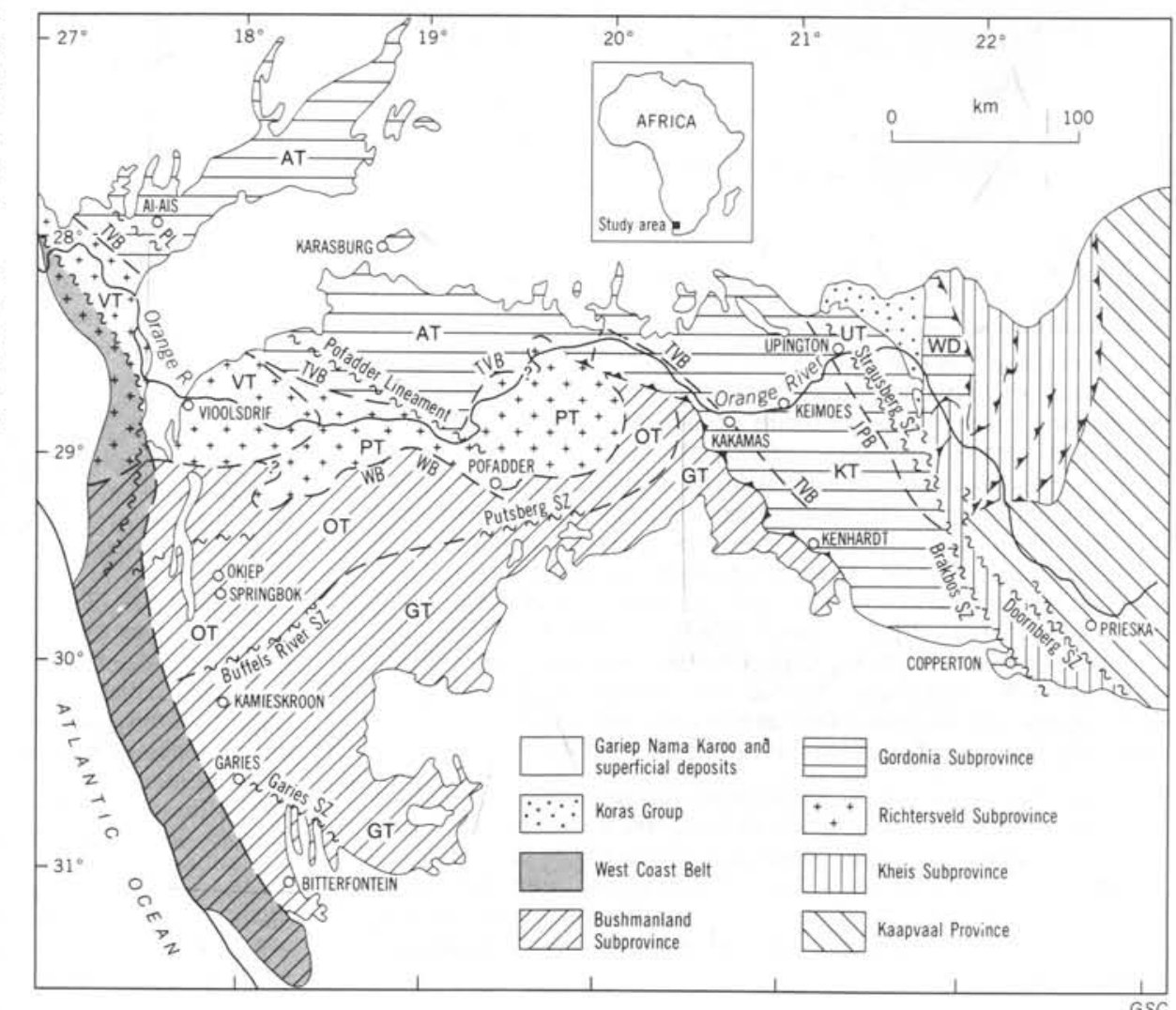


In the Bushmanland Subprovince, the Aggeneys Sequence hosts the giant stratiform base metal deposits of Aggeneys and Gamsberg (Fig. 6). A new depositional model (J.M. Moore, personal communication) for these metasedimentary paragneisses involves a three-fold division into (i) a northern continental/shallow marine quartzitic-aluminous facies, (ii) a central deeper marine facies of more biotitic gneisses and carbonate rocks, and (iii) a southern shallow marine facies of impure feldspathic quartzites and poorly sorted pelitic rocks. There is still some doubt about whether these facies were actually coeval in a single sedimentary basin, or represent different assemblages belonging to tectonically-juxtaposed, formerly separated terranes. Metavoleanic amphibolites in the upper part of the sequence have a $\mathrm{Sm}-\mathrm{Nd}$ isochron age of $1597 \pm 112 \mathrm{Ma}$ (P.J. Betton, personal communication, 1984). If problematic $\sim 1300 \mathrm{Ma} \mathrm{Pb}$ model ages (Koeppel, 1978) for the supposedly syngenetic, stratiform base metal ore deposits are ignored, then the Bushmanland metasedimentary gneisses probably accumulated between 1.7 and $1.6 \mathrm{Ga}$.

The dominant, mainly $\mathrm{E}-\mathrm{W}$ fabric in the Bushmanland Subprovince has been related to a regional metamorphism dated at $\sim 1.2 \mathrm{Ga}$ (Clifford et al., 1981). The main isoclinal folds are south-vergent and the large open, E-W trending, folds that extend across Bushmanland are a later phase. Subsequently, major and many minor shear zones developed, mainly dextral, on NW and ENE directions, followed along the west coast by the northerly trending, sinistral Pan-African shear zones and faults.

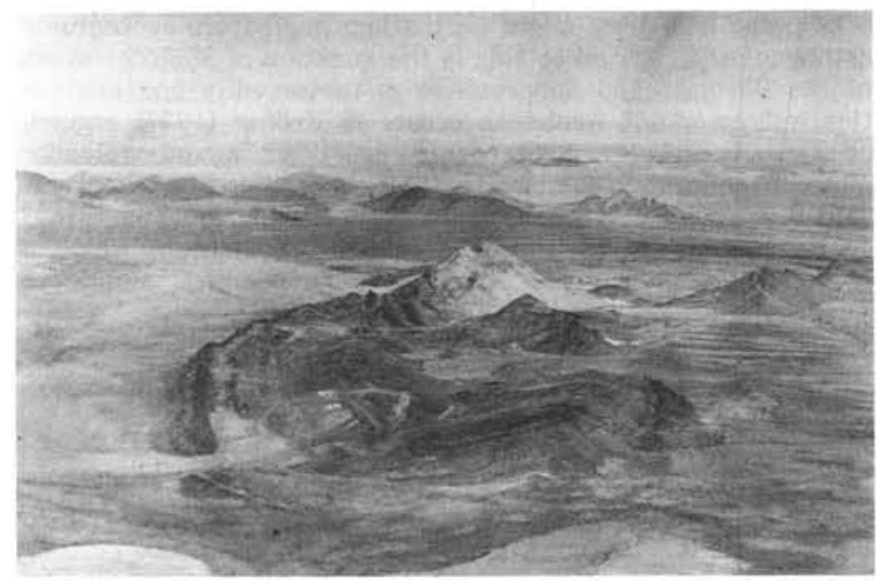

Figure 6: Aerial view of a large open fold structure in Bushmanland with Aggeneys Mountain in the background.

Extensive megacrystic and augen gneisses, dated at $\sim 1.2 \mathrm{Ga}$ and younger, intrude paragneissic rocks as subhorizontal concordant sheets of batholithic proportions. Their granitoid precursors were probably produced by crustal anatexis, reworking a $2.0-1.9$ Ga crustal protolith similar to the Vioolsdrif Suite and its associated metavoleanics (Reid and Barton, 1983). Late-tectonic granites followed and although geochemically variable, they are similar in appearance, field relationships and $\sim 1.2-1.1 \mathrm{Ga}$ isotopic ages. Emplacement of the late-tectonic plutons was subject to the NNW-oriented Gordonia tectonic control, superimposed obliquely across the regional $\mathrm{E}-\mathrm{W}$ Namaqua trend. Important copper-bearing mafic rocks and anorthosites, occur only within the region of granulite facies metamorphism, dated at $1.1 \mathrm{Ga}$.

Metamorphic zonation and thermal history in the western Namaqua Province reveals no detectable pressure variation but very steep palaeogeothermal gradients. D.J. Waters (personal communication, 1984) proposes that magmatic heat transfer in the crust explains the massive regional thermal anomalies in the highest grade metamorphic region of southern Bushmanland.
The northwest trending Gordonia Subprovince was at first a zone of convergent thrusting and folding, followed by an estimated minimum of $140 \mathrm{~km}$ of dextral shearing (Stowe, 1984). It incorporates a line of volcano-plutonic amphibolite complexes (Jannelsepan Formation) with calc-alkaline chemistry (Geringer, 1979), separating the Upington Terrane from the high-grade Kakamas Terrane (Fig. 3). Metamorphism at around $1.2 \mathrm{Ga}$ was followed by retrograde shearing at about $1.1 \mathrm{Ga}$. Its western margin is marked by the Tantalite Valley Bett (TVB on Fig. 5) of metagabbro, gabbronorite, troctolite, pyroxenite and peridotite intrusions as well as dyke-like amphibolite bands in augen-gneiss. Farther northwest a prominent band of amphibolite separates the Gordonia Subprovince from the sheared Richtersveld rocks. Around Luderitz, pyroxenite plugs and numerous serpentinites in gneisses indicate the possible northwesternmost extension of this $700 \mathrm{~km}$-long boundary line.

The Upington Terrane consists mainly of $2.0 \mathrm{Ga}$ quartzitepelite equivalents of the Kheis Subprovince sequence, overprinted by the main NW-trending Gordonia Subprovince folds and metamorphic zonation. Thrust-bounded structural domains of the Kheis Belt extend westwards into the Upington Terrane, where they are refolded, turned up on edge, and disrupted along the younger transcurrent shear zones so as to juxtapose lenticular crustal blocks of different stratigraphic, structural and metamorphic character (Stowe, 1983).

The northeastern boundary of the Upington Terrane is also the site of the Wilgenhoutsdrif Group, $1350 \mathrm{Ma}$ greenstones, including pillow basalts, jaspilite and associated voleaniclastic sediments, thrust northeastwards across the older Kheis Belt quartzites. Thin serpentinites with talc schist and black chert occur in the thrust zones. These thrusts and recumbent folds are the oldest Namaquan structures recognized in this region of the Gordonia Subprovince, affecting only the northeast boundary. Closure of this voleanic (back-arc?) basin by imbrication with the $1.3 \mathrm{Ga}$ Jannelsepan amphibolitic calcalkaline (arc?) complex, initiated the Namaquan orogeny, possibly by some form of arccontinent collision.

The Kakamas Terrane consists of 1.2-1.0 Ga juvenile crustal material and was subsequently the focus of late, transcurrent shears. Extensionally faulted basins developed along the northeastern outer margin of the Gordonia Subprovince, contain bimodal felsic-mafic volcanics and sedimentary rocks of the $\sim 1150 \mathrm{Ma}$ Koras Group east of Upington and of the Sinclair Sequence in southern Namibia.

The transition from the Jannelsepan amphibolitic complex to the Kakamas Terrane is abrupt across the main BrakbosDagbreek-Straussburg line of $\sim 1.1 \mathrm{Ga}$ shearing, and fold kinematic directions are totally different. Early isoclinal fold vergence changes from northeast in the Upington Terrane to southwest along the Bushmanland Subprovince boundary. Farther southeast, the Doornberg Line has been recognized as a major crustal discontinuity, conspicuous on the gravity surveys. This originated as a major thrust that was subsequently turned upon edge and was reactivated as a transcurrent shear (Coward and Potgieter, 1983; Stowe, 1984).

The Kakamas Terrane displays a northwest-trending fabric and was also the focus of the highest metamorphic grades, syn- to late-tectonic granites and charnockites. Around Kakamas (Fig. 3), the southwestern sector bordering the Bushmanland Subprovince consists of high-grade supracrustal rocks, distinctly different from either the Kheis or Bushmanland sequences. Paragneisses include "pink" leucogneisses, calc-silicates, quartzite and cordierite-sillimanite metapelite, interlayered with sheets of early-tectonic augen "grey" orthogneiss.

Early, syn- and late-tectonic plutons of the Gordonia Subprovince include 1.2-1.1 Ga biotite-hornblende gneissic granodiorites, non-foliated granitoids and charnockites. Geo- 
chemical and mineralogical comparison of a granite from north-west of Upington with a Koras Group quartz porphyry, indicates that the Koras volcanics probably represent an extrusive phase of the late-tectonic plutons in the Gordonia Subprovince.

Most recent interpretations of Namaqualand geology tend to support some form of plate convergence, although the evidence may still be questioned. $\mathrm{Sr}$ isotopic evolution models suggest that the Jannelsepan "arc" assemblage, Wilgenhoutsdrif Group greenstones, and the late-tectonic granites represent a major juvenile crust-forming event, no older than 1.3 Ga (Botha and Grobler, 1979; Barton and Burger, 1983). In view of the observed thrusting, serpentinites, Jannelsepan Formation and Wilgenhoutsdrif Group volcanic assemblages, the Kakamas Terrane might conceal a geosuture formed when the southwestern part of the Gordonia Subprovince, together with the Bushmanland Subprovince, each with their distinctive structures and cover sequences, converged with the Kaapvaal continental block. Southwesterly vergent overthrusting has been reported from the western margin of the Gordonia Subprovince and nappe structures from the Aggeneys region of Bushmanland. The Bushmanland and Richtersveld Subprovinces may therefore be part of an exotic, older (2.0-1.6 Ga) microcontinent, acereted behind the Jannelsepan "are" at about 1.3 Ga.

About $1800 \mathrm{~km}$ to the east in the Natal Belt, $1.2 \mathrm{Ga}$ lavas, tuffs and metasediments occur in a tectonic melange beneath the amphibolitic Tugela nappe complex in northern Natal (Fig. 1). This has also been described as a major accretion of isotopically juvenile material, interpreted as representing an ophiolite obduction episode (Matthews, 1972). Intrusion of charnockite continued until $\sim 950 \mathrm{Ma}$ ago, significantly after the $1.2 \mathrm{Ga}$ peak of high-grade metamorphism in the western Namaqua Province.

The younger, 1.1 Ga events in the western Namaqua Province and the Natal Belt might be explained by activation of a new, north-dipping, Cordilleran-type subduction zone, south of the previously accreted Natal-Bushmanland microcontinent, and along the Southern Cape Conductive Belt (De Beer and Meyer, 1983). Farther north, in the Gordonia Belt, transcurrent dextral shear and wrench fault zones developed along the old "suture," between the Gordonia and Kaapvaal Provinces, accompanied by uplift of extensive, high-grade regions in Namaqualand. During this event, diverse crustal lenses were tectonically juxtaposed along the main Brakbos and Doornberg shear systems (Fig. 5), late-tectonic granites were emplaced and the Koras Group "pull-apart" basins were formed. As summarized in the previous three paragraphs, the mosaic of diverse terranes in the Namaqua Province, may record multiple crustal suturing events.

Can the various "suspect terranes" and thrust-belts mapped along the northern and northeastern borders of Bushmanland and Gordonia be reconciled with the geophysical evidence suggesting oceanic subduction much farther south along the Southern Cape Conductive Belt? Does the Namaqua Province really conceal a cryptic record of multiple crustal amalgamation-accretion events? Did the first occur at $2.0 \mathrm{Ga}$, with convergence between the Richtersveld and Bushmanland Subprovinces? Was this followed at $1.3 \mathrm{Ga}$ by collision between this amalgamated Proterozoic microcontinent and the older Kheis-Kaapvaal continent? Did oceanic crustal subduction and further arc/microcontinent collision events continue along the Namaqua Province southern margin after $1.1 \mathrm{Ga}$ ?

These are some of the major questions posed by the Middle Proterozoic record of Southern Africa, to all of which a tentative "Yes" appears likely. Initial results of a new palaeomagnetic study of Namaqua rocks indicate that the various tectonostratigraphic terranes may be clearly distinguishable in patterns on NRM vector-component declination maps and

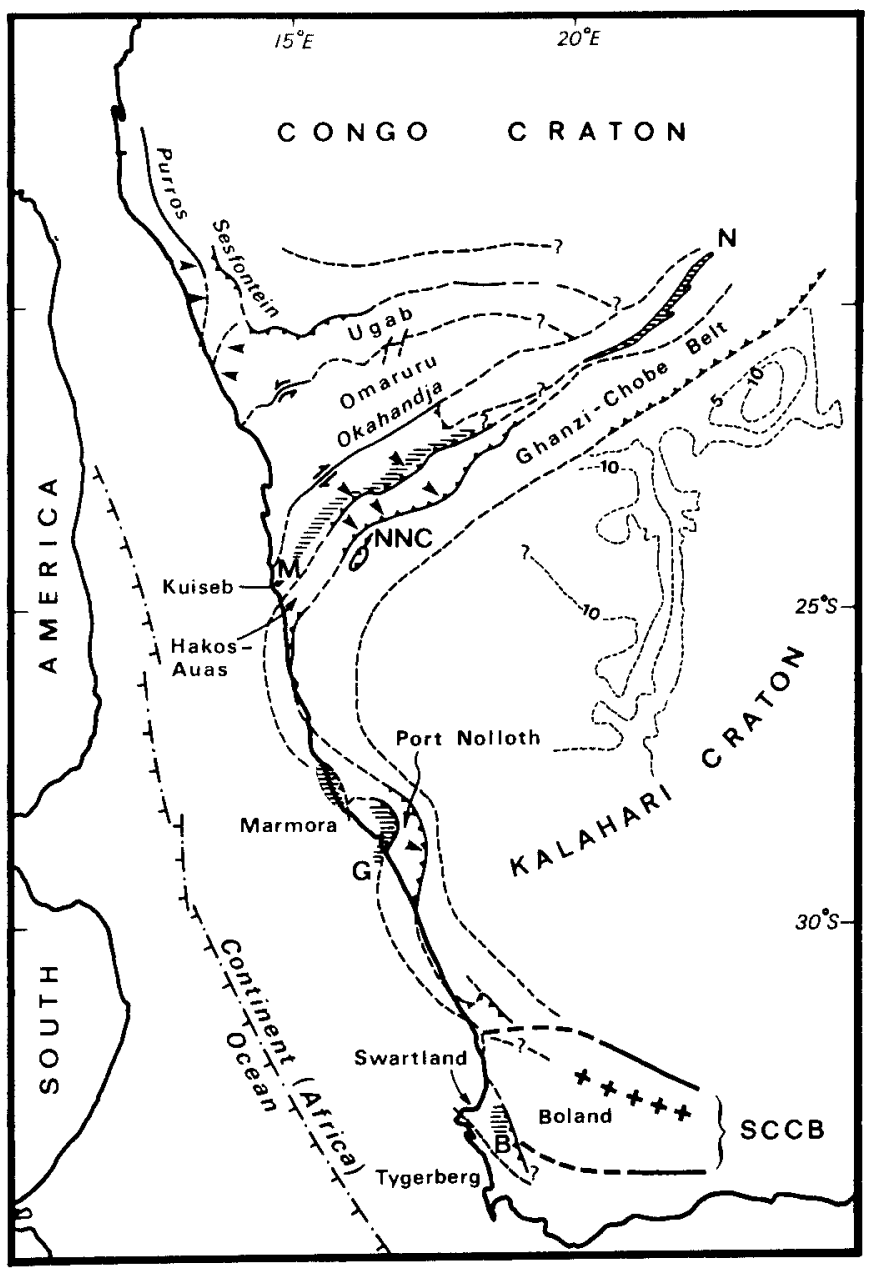

Figure 7: Pattern of tectonic terranes in the Damara Province. SCCB - "Southern Cape Conductive Belt." Horizontal hachures represent relict oceanic traces of the Adamastor geosuture: $N$ - Nokaneng basic body; NNC - Naukluft Nappe Complex; $M$ - Matchless Amphibolite; $G$ - Grootderm metabasalts; $B$ - Bridgetown metabasalts. $M, G$ and $B$ are linked by a prominent gravity anomaly on the inner continental shelf (dashed line). Late Proterozoic deep sedimentary basins, possibly floored by oceanic crust, are shown by $5 \mathrm{~km}$ to $10 \mathrm{~km}$ depth-to-magnetic-basement contours facing the marginal Ghanzi-Chobe Belt. Arrows denote tectonic vergence direction.

attempts are now being made to resolve different NRM acquisition ages by Ar-Ar thermochronometry (T.S. Onstott, personal communication, 1984).

\section{The Late-Proterozoic Damara Province}

The NE-SW trending branch of the Damara Orogen (Fig. 7) in central Namibia has been regarded as a typical example of intracratonic ensialic orogeny (Martin and Porada, 1977; Kröner, 1977) but geodynamic models involving various degrees of oceanic subduction have also been proposed (Hartnady, 1979; Barnes and Sawyer, 1980; Kasch, 1983). Summaries of Damaran geotectonic development have been provided recently by Coward (1983), Martin (1983) and Miller (1983a), covering also the cooperative work of groups from Britain (Leeds and Open University), Germany (Göttingen and Mainz) and South Africa (Council for Scientific and Industrial Research's National Geodynamics Programme involving several universities and state institutions). 
Studies in the Damara Province were particularly concentrated in, and therefore biased towards, a high-grade upper amphibolite facies, partially anatectically mobilized segment of the Damara Province in which exposed inliers of preDamaran crystalline basement rock are common. While easily accessible, superbly exposed, and well sectioned in the Namib Desert escarpment region, this area is atypical of the Damara Province as a whole.

In the southern, Gariep and Saldania Belts (Fig. 1), for example, regional metamorphic grades do not exceed the upper greenschist facies and older basement inliers are absent from their internal zones. They also contain a greater proportion of mafic-felsic low-grade metavolcanic material and a local abundance of immature semi-pelitic and metagreywacke rocks. The terrane composition here is thus more "ensimatic" or island-arc related. Intensive isotopic studies of the crustal evolutionary type have not yet been undertaken in these areas, but it seems reasonable to predict that, if and when they are, the conclusions might differ considerably from those of central Damara Orogen studies.

The Damara Orogen (s.s.) of Namibia can be divided into several contrasted tectonostratigraphic zones or terranes, but the major divisions occur between the N-S trending, coastal Kaoko Belt (actually the African direct extension of the Brazilian Mantiquiera Province - Torquato and Cordani, 1981) and the NE-SW trending, "intracratonic," northern Swakop Belt and southern Khomas Belts. The junction (Coward, 1983) at which these three subprovinces meet is concealed beneath the central Namibian continental margin deposits and the temporal order of tectonic movements and terrane juxtaposition around it is therefore not absolutely certain. The convergence between the Kaoko-Swakop Belt and the Congo craton is considered to have occurred earlier, followed by Swakop-Khomas Belt convergence or transcurrent shearing around $\sim 675-575 \mathrm{Ma}$ (Coward, 1983), culminating finally at $\sim 550-520 \mathrm{Ma}$ in southeastward overthrusting of the Khomas Belt onto the southern Kalahari craton margin.

Damaran $\mathrm{Sr}$ and Nd isotopic studies show that many granitic rocks were derived from pre-existing continental crust and little new crustal material was generated during the main thermal event around $550 \mathrm{Ma}$ (Hawkesworth and Marlow, 1983). Metasedimentary rocks low in the central Damaran sequence have isotopic characteristics very similar to the subjacent $2.0 \mathrm{Ga}$ basement, but those of semi-pelitic schists high in the sequence appear to reflect the influx of large guantities of much younger $(\sim 1.0 \mathrm{Ga})$ material (Hawkesworth and Marlow, 1983). Its source could be an "underplated" 1.0-1.3 Ga lower crustal layer, but mixing between even mantle-derived 550-750 $\mathrm{Ma}$ volcaniclastic material and 2.0 $\mathrm{Ga}$ upper crustal erosional detritus is also a possibility.

Geodynamic reconstructions of the Damaran Orogeny generally assume some kind of subduction (Martin, 1983) but divide over the relative importance of continental ("ensialic") and oceanic models. The former invoke an early aulacogenic rifting stage (Martin and Porada, 1977) followed by a contractional stage driven by asymmetric "de-lamination" of subcontinental lithospheric mantle on the southern side of the trough (Kroner, 1982). The oceanic models assume that rifting was succeeded first by a sea-floor spreading stage and then by conventional subduction, but they differ over the question of whether the oceanic lithosphere involved was relatively wide (Barnes and Sawyer, 1980; Kasch, 1983) or narrow (Miller, 1983a).

The Khomas Belt is the main focus of intense asymmetric thrust-and shear-belt deformation where the highest metamorphic pressures, about $10 \mathrm{kbar}$, have been determine by microprobe analysis of co-existing minerals (Kasch, 1983). It is not, however, the zone of highest regional metamorphic temperatures, or igneous plutonic activity, which is roughly confined to the southwestern Swakop Belt, just north of the Okahanja Lineament, associated with pressures in the 3-5
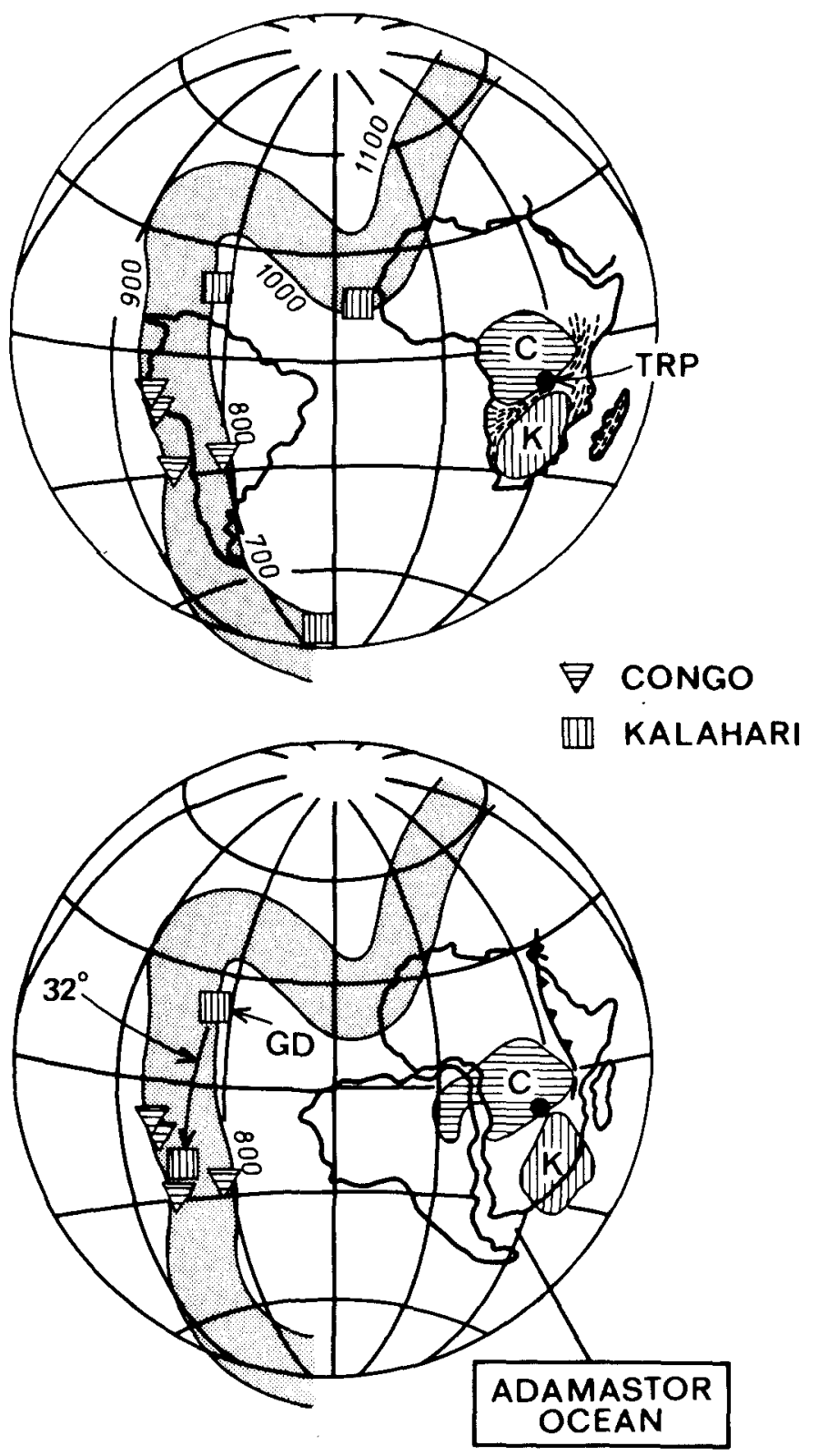

Figure 8: Geodynamic evolution of the Damara Province by closure of the Adamastor oceanic embayment. TRP is a tectonic rotation pole between late Proterozoic Kalahari $(K)$ and Congo (C) cratons, calculated from tectonic slip-vector data.

kbar range. Accordingly, the Khomas-Swakop pattern has been likened to a "paired," high $\mathrm{P}$ low T/low $\mathrm{P}$ high $\mathrm{T}$ metamorphic belt.

The southern Khomas zone is a deeply exhumed, southeasterly vergent fold-and-thrust belt, including a spectacular outlier klippe, the Naukluft nappe complex, and a variety of deeper thrust-system elements such as duplex structures, antiformal stacks and tectonic windows. Research is continuing on the stacking order, tectonic transport directions, later imbrication and partial refolding of thrust sheets in the southern marginal Khomas Belt or "Hakos-Auas Terrane." This correlates with new field evidence for the role of major overthrusting in the Gariep Belt to the south (Davies and Coward, 1982), and geophysical evidence of thrust belts along the buried northeasterly extensions in Botswana (Pretorius, 1984) and towards the Lufilian Are and Zambezi Belt of Zambia. 
The regional geometry of thrust zones and stretching lineations (Fig. 7) has recently been used to deduce tectonic transport in an evolving pattern of rigid-plate interaction at the complicated junction of the Lufilian-Zambezi (Damaran age) and Mozambique orogenic belts in Central Africa (Coward and Daly, 1984). Contrary to previous models of "ensialic" orogeny in the Zambezi Belt, there is now speculation that oceanic crust was completely consumed along the Khomas-Zambezi convergent subduction zones, the resulting geosutures having been later rendered "cryptic" by development of large-scale transcurrent shear belts, e.g., the Mwembeshi Zone in southern Zambia. Coward (1983) and Coward and Daly (1984) considered the Okahanja Lineament in central Namibia and the Mwembeshi Zone to be early sinistral shear belts.

The orientations of regionally consistent stretching lineations in central and southern Namibian thrust belts, and the largescale pattern of vertical shear belts in the Pan-African belts of Zambia and Malawi, can be used for quantitative palaeoplate-tectonic modelling (Hartnady, 1979). An Euler pole at $9^{\circ} \mathrm{S}, 28^{\circ} \mathrm{E}$ for convergent clockwise rotation of the Kalahari craton relative to the Congo craton (Fig. 8), assumes that the $\mathrm{MZ}$ and associated ENE-WSW (Luangwa-Kariba) shear belts are intracontinental transform structures with dextral shear sense. It also accounts for their apparent swing to more northerly trends in Malawi.

Late Proterozoic and older palaeomagnetic data from cratons on opposite sides of the Damara Province (McWilliams and Kroner, 1981) do not support wide ocean subduction models, although the Kalahari eraton data in the eritical 900-500 $\mathrm{Ma}$ time-interval is sparse and unreliable. A model of up to about $35^{\circ}$ of angular closure about the above-mentioned Euler pole seems permissible and implies that a narrow (500-1000 $\mathrm{km}$ wide in the Khomas Belt region), northeastwards tapering ocean was created and later subducted between the Kalahari and Congo cratons between 900-600 Ma.

Figure 8 includes a Gondwanaland apparent polar wander (APW) swathe for the 1,000-700 Ma period, including sparse data from both cratons. Rotating the Kalahari craton $32^{\circ}$ counter-clockwise about the tectonic rotation pole does not violate the APW swathe constraints, but actually groups the Gannakouriep Dyke swarm pole (GD on Figure 8) with East African palaeomagnetic data from similar $\sim 800 \mathrm{Ma}$ mafic voleanic and intrusive units. This approach resembles the Mesozoic-Cenozoic opening and partial closure of the Bay of Biscay during the Pyrenean phase of the Alpine orogeny. In such a scenario the Kalahari craton would be the Proterozoic analogue of the Iberian plate (Fig. 7).

The name Adamastor Ocean has been proposed by one of us (Hartnady) for this still hypothetical entity. Adamastor is a legendary demigod, turned to stone and personifying the Cape of Storms at the southern tip of Africa in an epic verse, the "Lusiad," by the 16th century Portuguese poet Camoes. Because of the Atlas and Iapetus association with names of "living" and "dead" North Atlantic oceans, this creative reworking of Greek mythology seems appropriate to apply in interpretations of the Damara Province in terms of the Wilson cycle. As a geotectonic concept, the Adamastor oceanic evolution not only provides a coherent explanation for a wide range of disparate phenomena in the southern Damara Orogen (Khomas Belt), Gariep, and Saldania Belts, but also has a bearing on interpretations of the Mesozoic development of the present rifted passive margin of the southwestern Atlantic.

Adamastor Ocean's relict existence in the southern Khomas Belt is indicated by the Matchless zone of MORB-like metavoleanic and metaplutonic mafic rocks (Miller, 1983b) and numerous serpentinite bodies of depleted mantle-type geochemistry (Barnes, 1982) that are closely associated with major S to SE-vergent thrust-faults. Geochemical data from the metavoleanic, "ophiolitic" Grootderm Formation in the Gariep Belt of southwestern Namibia indicate a "within- plate" ocean-floor setting with strong hotspot or "plumetype" magmatic source affinities (Hartnady and Smith, in preparation). The Grootderm thrust sheet appears originally to have formed a high-standing volcanic edifice, created by an enriched magmatic source distant from any nearby terrigenous sedimentary provenances. It may therefore be an accreted upper part of an oceanic island-seamount chain (Kröner, 1975), an aseismic ridge or small oceanic plateau. The possibly significant role of hotspot materials in continental growth is now becoming more widely appreciated.

The Adamastor Ocean might have widened southwards beyond the Gariep and Saldania Belts into the broader realms of the Pampean Province of southern South America and the Transantarctic Province bordering the ancient cratonic region of East Antaretica. These extensions of the PanAfrican or Brazilian orogenic systems (superprovinces) of West Gondwanaland appear to record a long history of "active margin" evolution between the Proterozoic supercontinent(s) and a Panthalassic Ocean, or perhaps a continuous evolutionary succession of different oceanic basins. The process of first accurately replacing this tectonic jigsaw puzzle into its end-Proterozoic configuration has barely commenced. Tracing it out fully over the previous $2.0 \mathrm{Ga}$ of Earth history promises to be an absorbing but fascinating task.

Dr. Chris Hartnady is based at the Precambrian Research Unit (Dept. Geology, Univ. of Cape Town, Private Bag, Rondebosch 7700 , South Africa), and has been involved in research and exploration in the Late Proterozoic Saldania, Damara, and Gariep Belts since 1966. $\mathrm{He}$ is also active in quantitative computer modelling studies, including research on the contemporary and Phanerozoic plate kinematics of Gondwanaland.

Prof. Pieter Joubert is Director of the Precambrian Research Unit. Previously a member of the Kenyan Mines and Geological Department and the South African Geological Survey, he has been involved in the exploration and study of Namaqualand since 1967.

Dr. Clive Stowe was a member of the Rhodesian Geological Survey and Reader at the University of Zimbabwe, prior to joining the Precambrian Research Unit. His research interests are structural geology and ore deposits, and he has worked on Proterozoic tectonics in the Northern Cape since 1979.
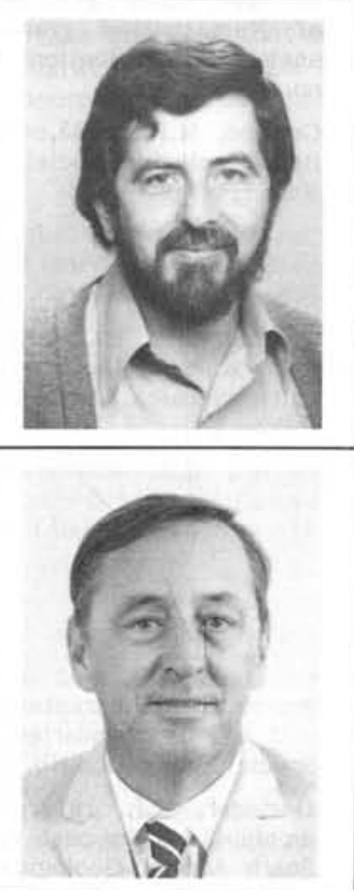
Barnes, S.-J., 1982. Serpentinites in central South West Africa/Namibia: a reconnaissance study. Geological Survey of S.W. Africa/Namibia, Memoir No. 8, 90p.

Barnes, S.-J. and Sawyer, E.W., 1980. An alternative model for the Damara Mobile Belt. Ocean crust subduction and continental convergence. Precambrian Research, v. 13, no. 4, p. 297-336.

Barton, E.S. and Burger, A.J., 1983. Reconnaissance isotopic investigations in the Namaqua Mobile Belt and implications for Proterozoic crustal evolution - Upington Geotraverse. Geological Society of South Africa Special Publication No. 10, p. 73-19l.

Blignault, H.J., Van Aswegen, G., Van der Merwe, S.W. and Colliston, W.P., 1983. The Namaqualand Geotraverse and environs: part of the Proterozoic Namaqua Mobile Belt. Geological Society of South Africa Special Publication No. 10 , p. $1-29$.

Botha, B.J.V. and Grobler, N.J., 1979. Models for the geotectonic evolution of the middle to late Precambrian Namaqua Mobile Belt in East Namaqualand, South Africa. Precambrian Research, v. 10, no. 1-2, p. 21-41.

Clifford, T.N., Stumpfl, E.F., Burger, A.J., MacCarthy, T.S. and Rex, D.C., 1981. Mineral-chemical and isotopic studies of Namaqualand granulites, South Africa: a Grenville analogue. Contributions to Mineralogy and Petrology, v. 77, no. 3 , p. $225-250$

Coward, M.P., 1983. The tectonic history of the Damara Belt. Geological Society of South Africa Special Publication No. 11, p. 409-421.

Coward, M.P. and Daly, M.C., 1984. Crustal lineaments and shear zones in Africa: their relationship to plate movements. Precambrian Research, v, 24, no. 1, p. 27-45.

Coward, M.P. and Potgieter, R., 1983. Thrust zones and shear zones of the margin of the Namaqua and Kheis Mobile belts, southern Africa Precambrian Research, v. 21, no. 1-2, p. $39-54$.

Davies, C.J. and Coward, M.P., 1982. The structural evolution of the Gariep Arc in southern Namibia (South-west Africa). Precambrian Research, v, 17, no. 3-4, p. 173-198.

De Beer, J.H., Van Zijl, J.S.V. and Gough, D.I., 1982. The Southern Cape Conductive Belt: its composition, origin and tectonic significance. Tectonophysics, v. 83, p. 205-225.

De Beer, J.H. and Meyer, R., 1983. Geoelectrical and gravitational characteristies of the Namaqua-Natal mobile belt and its boundaries. Geological Society of South Africa Special Publication No. 10, p. 91-100.

Geringer, G.J., 1979. The origin and tectonic setting of amphibolites in part of the Namaqua Metamorphic Belt, South Africa. Geological Society of South Africa Transactions, v. 82, no. 3, p. 287-303.

Hartnady, C.J.H., 1979. Quantitative description of Late Precambrian convergent finite motion between the Kalahari and Congo Plates during the formation of West Gondwana. International Union of Geodesy \& Geophysics XVII General Assembly (Canberra, Australia), Interdisciplinary Symposia Abstracts and Timetable, no. 17, p. 470.

Hawkesworth, C.J. and Marlow, A.G., I983. Isotope evolution of the Damara orogenic belt. Geological Society of South Africa Special Publication No. 11, p. 397-407.

Hutehins, D.G, and Reeves, C.V., 1980. Regional geophysical exploration of the Kalahari in Botswana. Tectonophysics, v. 69 , no. $3-4$, p. $201-220$.

Joubert, P., 1981. The Namaqualand Metamorphic Complex. In: Hunter, D.R. (ed.), Precambrian of the Southern Hemisphere, Developments in Precambrian geology 2, Elsevier, Amsterdam, p. 671-705.

Kasch, K.W., 1983. Continental collision, suture progradation and thermal relaxation: a plate tectonic model for the Damara Orogen in Central Namibia. Geological Society of South Africa Special Publication No. 11, p. 423-429.
Koeppel, V., 1978. Lead isotope studies of the stratiform ore deposits of Namaqualand, northwest Cape Province, south Africa and their implications on the age of the Bushmanland Supergroup. In: Zartman, R.E. (ed.), United States Geological Survey Open File Report 78-701, p. 223-226.

Kröner, A., 1975. Late Precambrian Formations in the Western Richtersveld, northern Cape Province. Royal Society of South Africa Transactions, v. 4l, no. 4, p. 375-433.

Kröner, A., 1977. Precambrian mobile belts of southern and eastern Africa - ancient sutures or sites of ensialic mobility? A case for crustal evolution towards plate tectonics. Tectonophysics, v. 40, no. 1-2, p. 101-135.

Kröner, A., 1982. Rb-Sr geochronology and tectonic evolution of the Pan-African Damara Belt of Namibia, southwestern Africa. American Journal of Seience, v. 282, no. 9, D. 1471-1507.

Martin, H., 1983. Alternative geodynamic models for the Damara Orogeny: A critial discussion. In: Martin, $H$. and Eder, F.W. (eds.). Intracontinental Fold Belts. Springer Verlag, Berlin, p. 913-945.

Martin, H. and Porada, H., 1977. The intracratonic branch of the Damara orogen in South West Africa. I. Discussion of geodynamic models. II. Discussion of relationships with the Pan-A frican Mobile Belt system. Precambrian Research, v. 5, no. 4, p. $311-338$ and p. 339-357.

Matthews, P.E., 1972. Possible Precambrian obduction and plate-tectonics in southeastern Africa. Nature, v. 240, no. 98, p. 37-39.

McWilliams, M.O. and Kröner, A., 1981. Palaeomagnetism and tectonic evolution of the Pan-African Damara Belt, southern Africa. Journal of Geophysical Research, v. 86, no. B6, p. 5147-5162.

Miller, R. MeG., 1983a. The Pan-African Damara Orogen of South West Africa/Namibia. Geological Society of South Africa Special Publication No. 11, p. 431-515.

Miller, R. McG., 1983b. Tectonic implications of the contrasting geochemistry of Damaran mafic volcanic rocks, South West Africa/Namibia. Geological Society of South Africa Special Publication No. 11, p. 115-138.

Porada, H., Ahrendt, H., Behr, H.-J. and Weber, K., 1983. The join of the coastal and intracontinental branches of the Damara Orogen, Namibia, South West Africa. In: Martin, H. and Eder, F.W. (eds.). Intracontinental fold belts, p. 901-912.

Pretorius, D., 1984. The Kalahari Foreland, its marginal troughs and overthrust belts, and the regional structure of Botswana. Economic Geology Research Unit, University of the Witwatersrand, Information Circular No. 169, p. 1-24.

Reid, D.L., 1982. Age relationships within the Vioolsdrif batholith, lower Orange River region. II. A two stage emplacement history and the extent of Kibaran overprinting. Geological Society of South Africa Transactions, v. 85, no. 2, p. $105-110$.

Reid, D.L. and Barton, E.S., 1983. Geochemical characterization of granitoids in the Namaqualand geotraverse. Geological Society of South Africa Special Publication No. $10, \mathrm{p}, 67-82$.

Stowe, C.W., 1983. The Upington Geotraverse and its implications for craton margin tectonics. Geological Society of South Africa Special Publication No. 10, p. 147-171.

Stowe, C.W., 1984. Explanation of the Upington Geotraverse, South Africa. In: Rast, N. and Delany, F.M. (eds.), Profiles of orogenic belts, International Geodynamics Series, American Geophysical Union v. 10, p. 35-44.

Stowe, C.W., Hartnady, C.J.H. and Joubert, P., 1984. Proterozoic tectonic provinces of Southern Africa. Precambrian Research, v. 25 , no. 1-3, p. 229-231.

Torquato, J.R. and Cordani, U.G., 1981. Brazil-Africa geological links, Earth Science Reviews, v. 17, p. 155-176. 